\title{
Performance Management System of R\&D Personnel in High-Tech Enterprises in China -Based on PDCA Cycle Perspective
}

\author{
Yalan Wang \\ College of Management \\ Wuhan University of Science and Technology \\ Hubei, China \\ 595136412@qq.com
}

\begin{abstract}
With the continuous improvement of science and technology, all industries in China have entered a new stage. Among which the development of high-tech enterprises is showing new features. $R \& D$ personnel as the core elements of innovation and development of such enterprises, the level of its management directly affects the survival and development of enterprises. This paper chooses the $R \& D$ personnel in high tech enterprise of China as research objects to explore the status and problems of its innovative performance management. Based on the perspective of PDCA, this paper puts forward reasonable suggestions and countermeasures for the construction of performance management system. It is hoped that the practice of improving the performance of $R \& D$ personnel will be discussed theoretically.
\end{abstract}

Keywords-R\&D personnel; high-tech enterprises; PDCA cycle ; performance management

\section{INTRODUCTION}

This With the development of science and technology, economic globalization is developing at a high speed. The era of knowledge economy has arrived. Especially since 2008, in the background of Post Financial Crisis Era, enterprises need to continue to increase R\&D investment, enhance innovation capability and build core competitiveness in order to completely shake off the impact of the financial crisis and aftershocks. Booz's survey on the largest budget among 1000 enterprises in 2011 showed that its total R\&D investment up to $\$ 603$ billion[1]. Kyoto Tilly’s International Business Report in 2010 displayed that domestic enterprises' willingness to increase $R \& D$ investment was ranked first in the world. The "optimism / pessimism index" in R\&D investment reaches to $52 \%$ whereas the global average is only $25 \%$. The extensive development of $R \& D$ activities makes the demand for $R \& D$ personnel in our country increase. The introduction, development and maintenance of $R \& D$ personnel in high-tech enterprises have become a hot and difficult issue in theoretical research and practice.

R\&D personnel as the core driving force of research and development in the high tech enterprise are the most dynamic and creative heterogeneous of human capital. It is the most important driving force and core source to promote the development of enterprises. The heterogeneity of R\&D personnel's personality, behavior and demand determines the particularity of its management means. When it brings new vitality and competitiveness into the enterprise, it also makes the management of R\&D personnel, especially its performance management become an urgent problem to be solved. Performance management is not only an effective tool to achieve the key objectives of the enterprise, but also an important lever to promote the incentive effect. Therefore, to give full play to the incentive function of performance management and design scientific performance management system is very important to manage the performance of $R \& D$ personnel for the development of enterprises.

\section{DEFINITION AND CHARACTERISTICS OF R\&D PERSONNEL IN HIGH-TECH ENTERPRISES}

R\&D personnel in high tech enterprise are mainly engaged in technological innovation that they are typical knowledge workers[2]. R\&D people are the owners of knowledge, so their investments in high tech enterprise are far from the human body itself. It includes knowledge that is element for production and development of high-tech enterprises[3]. About the concept of R\&D personnel in high-tech enterprises, there are different scholars have put forward different views, but in fact the core meaning is consistent. Based on the research and analysis of knowledge workers at home and abroad, this paper defines the R\&D personnel in high-tech enterprises as people who master and use of knowledge to engaged in high-tech research, high-tech product development and technological innovation in enterprise. Compared with the general staff, the R\&D staffs of high-tech enterprises have the following characteristics:

\section{A. High scarcity}

R\&D personnel are the most valuable assets of high-tech enterprises. Their high scarcity is that they have an unknown coding knowledge that is not available to everyone who has received formal education from the school because it requires considerable expertise and experience. 


\section{B. Strong achievement motivation}

R\&D staffs usually have a higher level of demand that they put more emphasis on the need for self-realization.

\section{The work process is not easy to monitor}

They are mainly engaged in creative work, so the work process is not easy to monitor. As the carrier of knowledge resources, R\&D staffs are not like the workers in Taylor's assembly line who are engaged in a simple duplication of work. Instead they need to rely on their own knowledge to give full play to the wisdom of individuals, inspiration and creativity to complete the work in a volatile and uncertain system.

\section{Their work results are difficult to measure and evaluate}

First of all, the results of R\&D staffs' works are often in a form of creative thinking, technological innovation and management innovation, so it often does not have a direct measurement of the economic form. Then, the innovation and research works of $R \& D$ personnel have the risk and the uncertainty of the results time. Finally, R\&D staffs often need to form a team of mutual cooperation and complementary advantages to collectively overcome difficulties, so the results of their work are the crystallization of the wisdom of the team rather than the individual's achievement. Therefore, it is difficult to assess the performance of R\&D personnel.

\section{E. Pay more attention to knowledge and despise authority}

Knowledge workers have a deep understanding of the development trends and deficiencies in the field of technology that they are engaged in with deep professional knowledge and experience, so they believe in their own judgment. Therefore, they do not blindly follow authority. The interest of knowledge workers is focused on the use of professional knowledge. They tend to be more motivated by their personal career development than their loyalty to the enterprise. Considering their talent and creativity, they enjoy challenging jobs, so there is strong job liquidity among them. Through the changing job, they can enhance their values.

\section{PRESEnt SituAtion AND PROBlems OF PERFORMANCE MANAGEMENT OF R\&D PERSONNEL IN HIGH-TECH ENTERPRISES OF CHINA}

Driven by the economic globalization, many domestic enterprises have gradually realized the importance of performance management system. They begin to learn from foreign advanced theory and methods of performance that introduces strategic goal oriented closed loop system of performance management system into China. For the hightech enterprises in our country, they have a certain degree of understanding towards the concept of performance management and the importance of R\&D personnel. However, in the specific management strategy, they still use the traditional performance evaluation methods and ideas[3], so there are many problems in the performance management of R\&D personnel.

\section{A. Performance management system is not perfect}

Although many high-tech enterprises have established internal staff management system, there is no internal systematic performance management system. There exists misunderstanding that they regards performance appraisal as performance management. In addition, it lacks of performance goal setting and performance feedback that makes the performance appraisal and performance goals out of line. At the same time, the evaluation standard of staff management system is not accurate. In the setting of employee's performance indicators, the performance indicators are too many and confusing. At present, the key indicators of R\&D personnel performance evaluation index in high-tech enterprises include the research target achievement rate and customer development rate. Performance appraisal is more inclined to work results and seriously lacks of process indicators in performance evaluation.

\section{B. Mistake performance management as a matter of HR department}

Typically, performance management is organized by the human resources department. Therefore, other departments, especially the research and development department thinks that performance management is a matter of the HR department. Just after the completion of the research and development tasks, they give the results to the human resources department for evaluation. However, due to the special nature of $\mathrm{R} \& \mathrm{D}$ works and HR department lacks of understanding of the content and nature of the works, it may lead to bias in performance evaluation.

\section{Low scientific of performance evaluation index}

At present, on the one hand, a lot of high-tech enterprises in our country adopt performance indicators which depend on the completion of business objectives that is task performance. On the other hand, it is a series of factors of staffs, such as work attitude and ideology that is peripheral performance. In the assessment of peripheral performance, all the indicators are almost all around the results to start that ignores the importance of the working process[4]. At the same time, because it is an artificial assessment in the process of evaluation, it is inevitable to add some personal assessment of the judges that lacks of persuasion, so it is difficult for employees to recognize and convince. In the process of evaluation of employee's behavior, it can't objectively assess it. Such standards will inevitably have a certain discrepancy with the actual results that makes the examination result is not ideal.

\section{Performance management of $R \& D$ personnel lack of incentives}

The current performance management system in most of China's high-tech enterprises lacks of effective incentives. R\&D personnel have strong motivation for achievement that they usually have a higher level of demand and pay more attention to the needs of self-realization. Traditional incentives for R\&D personnel have lost the incentive function. This kind of performance management for $R \& D$ personnel lost its original meaning. 


\section{CONSTRUCTION OF R\&D PERSONNEL PERFORMANCE MANAGEMENT SYSTEM BASED ON PDCA}

PDCA cycle is a general model of management which is used in the process of continuous improvement of product quality[5]. The cycle consists of four phases that are plan, do, check and action. Domestic enterprises apply it into employee's performance management with their own practice and have made many achievements. Based on PDCA perspective, performance management can be seen as a continuous cycle of performance planning, performance coaching, performance appraisal, performance diagnosis and improvement[6].

\section{A. Plan: performance planning and index setting}

Performance planning is the basic process of performance management and the first process of performance management system. The performance plan should be based on the analysis of the object. R\&D personnel are engaged in the development of new products or services to create new activities that the content of their work often starts with an idea or customer requirements. Such ideas and requirements are subject to restrictions of market, information and incomplete expectations for the future, so there is no strict job analysis document as the basis for work. Therefore, it should take full account of the particularity of the work content when making the performance plan. To measure the performance of R\&D personnel should not only pay attention to the results, but also pay attention to every aspect of the innovation process. Then, it is the setting of indicators. In view of the particularity of high-tech R\&D activities, the performance evaluation indicators should be made from two perspectives: process performance and output performance. In the process of innovation, knowledge discovery, process improvement and cooperation atmosphere are all the key factors that influence the innovation performance of $\mathrm{R} \& \mathrm{D}$ personnel. At present, domestic and foreign scholars as well as enterprises have recognized the innovation ability, innovation behavior, innovation process and innovation achievement as the first level indicators. Among them, innovation ability, innovation behavior and innovation process are the embodiment of process performance while innovation achievement is the embodiment of output performance.

\section{B. Do: performance coaching communication}

Continuous performance communication and coaching is the process by which managers and employees share information about performance in the process of working together. The performance management of R\&D personnel is more dynamic and interactive[7]. In the performance management work, it should keep track of the employee's current work on a regular basis. At the same time, R\&D personnel are knowledge workers that they tend to attach importance to knowledge and despair authority. The leaders of R\&D departments are usually technical experts. Therefore, in the implementation of performance management, it is necessary to give full play to the role of the department's team leader. It should not just consider the performance appraisal of R\&D personnel as a matter of human resource management. At the same time, it is necessary to pay special attention to its communication and interaction that can't rely solely on the use of systems and performance incentives to restrain their behavior in order to achieve the purpose of performance objectives.

\section{Check: evaluation of performance appraisal results}

In The application of performance appraisal results is the key to the success of performance management. At present, the results of performance appraisal in most of the high-tech enterprises in our country are only linked to wages that is the pure economic incentives. In fact, this is unscientific. R\&D personnel have high achievement motivation, so traditional incentive measures, such as performance pay, incentive compensation and employee benefits are to be conservative for them. At present, academic circles and enterprises generally believe that the effective incentive measures are equity incentive and technology shares. Therefore, enterprises should combine the performance evaluation results of $R \& D$ personnel with these effective incentives. In addition to the above purposes, the performance evaluation results should also focus on the development of staff. On the one hand, the performance evaluation results can be used to analyze the field that $R \& D$ personnel can produce good performance to provide multiple career paths for R\&D personnel. On the other hand, it can provide the basis for the formulation of employee's training needs.

\section{Action: performance diagnosis and improvement}

Generally speaking, performance feedback is a positive communication between managers and examiners towards performance evaluation results of the last performance cycle. In the process of performance management of R\&D personnel, the feedback should be ubiquitous. It is based on the interaction between system elements that is the source of performance improvement for R\&D personnel. There are two types of feedback in the performance management process of R\&D personnel: feedback based on performance control and feedback based on performance after control. R \& D personnel are often engaged in a pioneering and challenging work. In many cases, the criteria set forth in the pre-established performance objectives may not reflect the true requirements of task performance. Therefore, it should have objective and fair evaluation towards performance of R\&D personnel. Finally, in the feedback, we should focus on two-way interaction. It should follow the principle of aimed at things instead of person and positive guidance to create a positive and harmonious atmosphere.

\section{Conclusions}

The above four parts is a complete process of the performance management system of PDCA cycle. In the performance management, each round of PDCA cycle can promote the improvement of enterprise performance management and bring lasting power for enterprise performance management. Its development is not a linear development, but it presents a spiral rise with time going by. Like endless quality management, performance management is a process in which change is used to cope with change. It has to rely on plan, do, check and action to find solutions. The 
PDCA cycle method can help the performance management of R\&D personnel in high-tech enterprises to be closer to the actual situation and the current situation. It can make the development of performance management to a direction of a virtuous circle. Through its implementation and skilled use, it can form a spiral performance management system.

\section{REFERENCES}

[1] The Economist R\&D spending [DB/OL]. [2012-10-30].
[ http://www.economist.com/blogs/graphicdetail/2012/10/focus-7.

[2] Wang M C, Yan R H. Analysis of the Factors Affecting the Loss of the R\&D Personnel in High-tech Enterprises based on ISM[J]. Scientific Management Research, 2014.
[3] Wang H, Zhao Y, Cao J. An empirical study on the relationship between $\mathrm{R} \& \mathrm{D}$ input and profitability of high-tech enterprises in China[C]// International Conference on Computer Science and Service System. IEEE, 2011:1077-1079.

[4] J Hu L, Guo Y, Yi P. Method and Its Application of Performance Evaluation of R\&D Personnel in High-tech Enterprises[J]. Technology Economics, 2009.

[5] Lei X. PDCA Cycle in the Disinfection Supply Center,the Application of Continuous Quality Improvement[J]. China Health Industry, 2015, 95(20):11834-11839.

[6] Du Q L, Cao S M, Ba L L, et al. Application of PDCA Cycle in the Performance Management System[C]// International Conference on Wireless Communications, NETWORKING and Mobile Computing. IEEE Xplore, 2008:1-4.

[7] Cai H, Qin X. Study on Performance Management of Enterprise R\&D Staff[M]. IEEE Computer Society, 2009. 